\title{
Total Plate dan Total Staphylococcus aureus pada Daging Di Pasar Tradisional Kecamatan Mulyorejo Surabaya
}

\section{Total Plate and Total Staphylococcus aureus in Carcass at Traditional Markets Mulyorejo Sub-District Surabaya}

\author{
Nonie Olivia Adia Mutiarasari ${ }^{1}$, Nenny Harijani ${ }^{2}$, Fedik Abdul Rantam ${ }^{3}$, Dadik \\ Raharjo $^{2}$, Agnes Theresia Soelih Estoepangestie ${ }^{2}$, Didik Handijatno ${ }^{3}$ \\ 1Student, ${ }^{2}$ Department of Veterinary Public Health, ${ }^{3}$ Department of Veterinary \\ Microbiology, Faculty of Veterinary Medicine, Universitas Airlangga \\ Corresponding author: nonie.olivia.adia-2015@fkh.unair.ac.id
}

\begin{abstract}
This study aimed to evaluate the Total Plate Count and total Staphylococcus aureus count of beef sold in wet markets in Mulyorejo sub-district below the National Standard Indonesia (SNI 7388:2009) about maximum limit of microbial contamination in food or not. Total of twenty four samples of beef purchased from traditional markets of Tempurejo, Krempyeng Yamuri, Pacar Keling, and Menur in Mulyorejo sub-district Surabaya were examined by Total Plate Count using pour plate method. The sample was also cultured in Mannitol Salt Agar. The colony suspected to be S. aureus were taken for identification. The identification of $S$. aureus consists of isolation in Mannitol Salt Agar, Gram staining, catalase test, and coagulase test. Total plate count result showed that four samples were exceeding the National Standard of Indonesia SNI 7388:2009 or $1 \times 10^{6} \mathrm{CFU} / \mathrm{g}$ and the rest were below the maximum Total Plate Count in SNI. The highest Total Plate Count result was $1,9 \times 10^{6} \mathrm{CFU} / \mathrm{g}$ and the lowest was $7,8 \times 10^{4} \mathrm{CFU} / \mathrm{g}$. The result of identification showed that $100 \%$ samples examined were contaminated by $S$. aureus with the highest result was $2,9 \times 10^{4} \mathrm{CFU} / \mathrm{g}$ and the lowest result was 4,3x103 $\mathrm{CFU} / \mathrm{g}$ or exceeding the SNI 7388:2009.
\end{abstract}

Keywords: Total plate count, Staphylococcus aureus, fresh beef

Received: 08-09-2020 Revised: 09-10-2020 Accepted: 10-11-2020

\section{INTRODUCTION}

Meat is all the body tissues of animals, and all products processed by these tissues, which can be eaten, and does not cause health problems for those who eat them, including the liver, kidneys, brain, lungs, heart, spleen, pancreas, and tissues muscle. Meat can be divided into three groups, such as red meat, white meat and meat from aquatic animal (Fikri et al., 2018). Red meat is group of meat origin from livestock animal (cattle, buffalo, goat, lamb, swine, horse, deer, etc.). White meat is group of meat origin from poultry (chicken, duck, quail, etc.). The third group is meat that derived from aquatic animals both fresh water and sea such as fish, lobster, shrimp, shellfish. (Nurhadi, 2012). Red meat contains high biological value proteins and essential micronutrients, including vitamins and minerals (International Agency for Research on Cancer, 2018). Beef is one source of animal protein that is easily found in Indonesia. It is the most desirable protein source after chicken meat and eggs.

Foodborne disease is an illness caused by food or drink which had been contaminated with pathogenic microbes (Naully and Mathilda, 2018). Some diseases caused by food from livestock 
are anthrax, salmonellosis, brucellosis, tuberculosis, clostridiosis, and consequent disease contamination of Staphylococcus aureus (Supar and Ariyanti, 2005). According to Badan Pengawas Obat dan Makanan Republik Indonesia (2017), from 53 outbreaks of food poisoning that occurred, the highest causative agent was microbiology with an estimated 24 events or about $45.28 \%$ and as many as 7 events or about $13.21 \%$ are confirmed agent. A total of 15 events or about $28.30 \%$ were unknown, and the rest were caused by chemical agents. Microbiological agents confirmed to be the cause of food poisoning outbreaks are $S$. aureus as many as 6 events and $S$. aureus with Bacillus cereus for 1 event (Fikri et al., 2017).

There are several things causing food to become contaminated by pathogenic microbes, including processing, presentation, and incorrect storage method (Arisanti et al., 2018). The main sources of contamination are human handlers contaminate food via manual contact or via the respiratory tract by coughing and sneezing, and contamination occurs after heat treatment of the food (Fikri and Purnama, 2020). In foods such as raw meat, sausages, raw milk, and raw milk cheese, contaminations from animal origins are more frequent and from animal carriage or from infections like Mastitis (Le Loir et al., 2003). Some pathogenic microbes that usually contaminates beef is E. coli, Salmonella, and S. sp. (Djaafar and Rahayu, 2007). Some $S$. aureus strains are the causative agents of staphylococcal food poisonings because these bacteria are able to produce Staphylococcal Enterotoxins (SEs) (Le Loir et al., 2003). Enterotoxin is a major cause of Staphyococcal food poisoning in foods that contain carbohydrates and proteins because of its heat resistance and resistance of alkaline atmosphere in the intestine (Brooks et al., 2008)

\section{METHODS \\ Design of study}

This research was descriptive exploratory research using purposive sampling with the size of twenty four samples. Each sample consist of $25 \mathrm{~g}$ beef sold at wet markets in Mulyorejo subdistrict. This research has been carried out within four weeks with sampling done per market every week. The first week of sampling was conducted at Tempurejo market, the second week at Krempyeng Yamuri market, the third week at Pacar Keling market, and the fourth week at Menur market.

\section{Sample collection}

Six samples were taken for testing each week. Samples were collected from wet market from 5:30 AM to 7:00 AM, put in plastic bags and labeled. Then stored in a cool box containing ice packs and taken for testing in the laboratory of Veterinary Public Health and laboratory of Bacteriology and Mycology Faculty of Veterinary Medicine, Universitas Airlangga.

\section{Sample preparation}

Each sample of $25 \mathrm{~g}$ beef were cut and weighed, put in Erlenmeyer containing $225 \mathrm{ml}$ of Buffer Peptone Water (BPW) then homogenized (dilution $\left.10^{-1}\right) \cdot 10^{-2}$ dilution were made by taking $1 \mathrm{ml}$ of the homogenized solution then transferred to the test tube containing 9 $\mathrm{ml}$ of Buffer Peptone Water (BPW) using pipette. Then continue until dilution 105.

\section{Total Plate Count (TPC)}

The results of $10^{-3}, 10^{-4}$, and $10^{-5}$ dilution were taken $1 \mathrm{ml}$ each then grown on Nutrient Agar (NA) media on duplo petri dish with pour plate method. Petri dishes with bacteria as many as 30-300 colonies were selected and the number of bacteria were counted. 


\section{S. aureus isolation and count}

The results of $10^{-1}, 10^{-2}$, and $10^{-3}$ dilution were taken $0,1 \mathrm{ml}$ each then cultured in Mannitol Salt Agar (MSA) media using spread method. Colony that grow apart and suspected $S$. aureus was streaked on Mannitol Salt Agar (MSA) media prepared on petri dish. The petri dishes were incubated upside down at $37^{\circ} \mathrm{C}$ for 24 hours. Petri dishes with bacteria as many as 30-300 colonies were selected and the number of bacteria were counted.

\section{Identification of S. aureus Gram staining}

Gram staining was a staining method using crystal violet, lugol, alcohol, and safranin then observed under the microscope with the magnification of $1000 x$.

\section{Catalase test}

Catalase test was done by sterilizing the object glass and a loop of bacteria isolate placed above the object glass. Then $\mathrm{H}_{2} \mathrm{O}_{2} 3 \%$ was dropped above the object glass. The appearance of gas bubble indicates positive reaction.

\section{Coagulase test}

The coagulase test was carried out by mixing the bacteria isolate with $1 \mathrm{ml}$ blood plasma then incubated at $37^{\circ} \mathrm{C}$ for 24 hours. The positive reaction appeared when the blood plasma clotted.
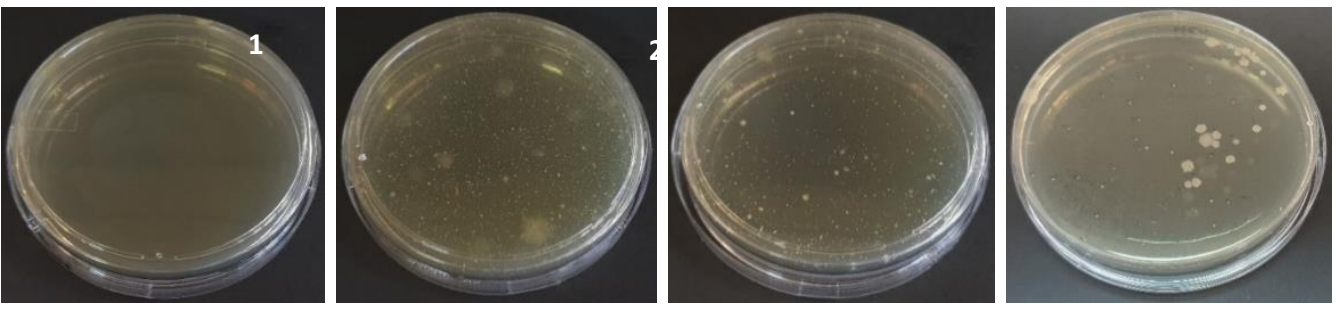

Figure 1. Bacterial growth on Nutrient Agar (NA) media: control $\mathrm{M}$ with no bacteria growth (1), Total Plate Count of sample $\mathrm{M}_{\mathrm{A}}$ dilution $10^{-3}$ (2), sample $\mathrm{M}_{\mathrm{A}}$ dilution $10^{-4}$ (3), and sample $\mathrm{M}_{\mathrm{A}}$ dilution $10^{-5}(4)$. The colonies appeared as white circles and the TPC result for sample $\mathrm{M}_{\mathrm{A}}$ was $1,9 \times 10^{6} \mathrm{CFU} / \mathrm{g}$. 

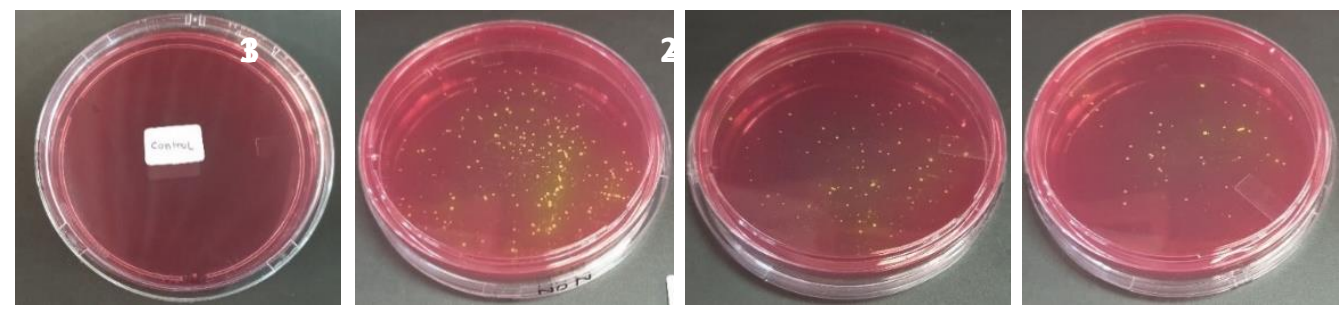

Figure 2. S. aureus growth on Mannitol Salt Agar (MSA) media: control K with no bacteria growth (1), S. aureus isolation from sample $K_{A}$ dilution $10^{-1}(2)$, sample $K_{A}$ dilution $10^{-2}(3)$, and sample $\mathrm{K}_{\mathrm{A}}$ dilution $10^{-3}$ (4) with the colonies appeared as yellow circles and the color change of the media from red to yellow surround the colonies. The $S$. aureus count result for sample $\mathrm{K}_{\mathrm{A}}$ was $4,9 \times 10^{2} \mathrm{CFU} / \mathrm{g}$.

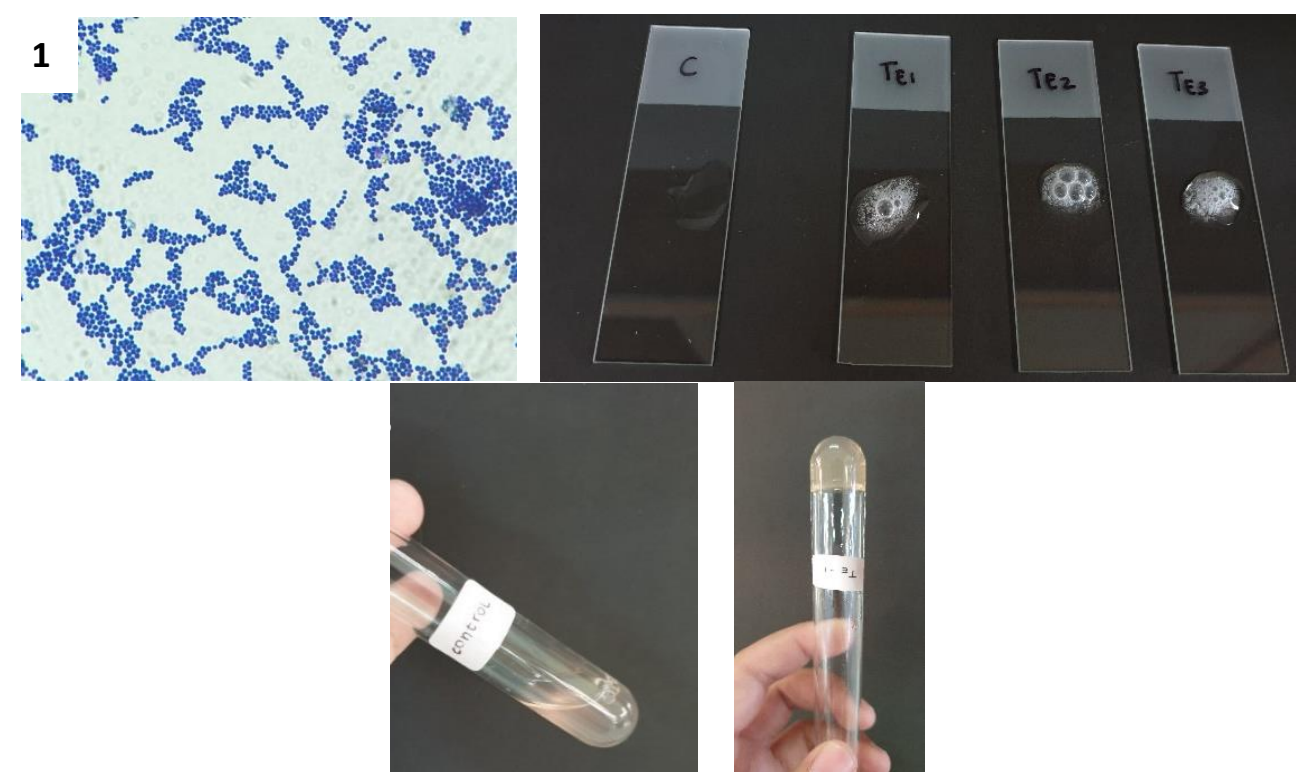

Figure 3. Identification of $S$. aureus: Microscopic picture of $S$. aureus from sample $T_{E}$ with Gram staining with the magnification of 1000x. These bacteria shown as roundshaped in the form of clusters. S. aureus is a Gram-positive bacterium, so they appeared in purple color (1). Catalase test from sample $\mathrm{T}_{\mathrm{E}}$ showed positive reaction. $S$. aureus can breakdown $\mathrm{H}_{2} \mathrm{O}_{2}$ into $\mathrm{H}_{2} \mathrm{O}$ and $\mathrm{O}_{2}$, so the gas bubble appeared after dropping $\mathrm{H}_{2} \mathrm{O}_{2} 3 \%$ (2). Coagulase test for control $\mathrm{T}$ with no clotted plasma (3) and for sample TE showed positive reaction. S. aureus can change fibrinogen into fibrin, so the plasma clotted (4).

\section{DISCUSSION}

Based on the result obtained from Total Plate Count (TPC) on beef in Tempurejo, Krempyeng Yamuri, Pacar Keling, dan Menur Wet Market in Mulyorejo Sub-district Surabaya, from 24 sample taken, there were 4 samples whose TPC results surpassed the Standard Nasional Indonesia 7388:2009 or $1 \times 10^{6} \mathrm{CFU} / \mathrm{g}$. Sample exceeding the SNI 7388:2009 were sample $K_{B}$ for 1,5 x $10^{6} \mathrm{CFU} / \mathrm{g}$, sample $\mathrm{K}_{\mathrm{E}}$ for $1,4 \times 10^{6}$
$\mathrm{CFU} / \mathrm{g}$, sample $\mathrm{M}_{\mathrm{A}}$ for $1,9 \times 10^{6} \mathrm{CFU} / \mathrm{g}$ and sample $\mathrm{M}_{\mathrm{E}}$ for $1,7 \times 10^{6} \mathrm{CFU} / \mathrm{g}$.

The difference between the TPC value were influenced by the environment around the stalls. Almost all traders used the same knife to cut meat and separate the offal. Based on observations in the markets, it can be concluded that the market environment, meat stalls, equiptments, as well as water used on the market can affect the level of the Total Plate Count (TPC). 
There are several factors that can cause bacterial contamination in meat, such as hair, feathers (poultry), skin, contents of the digestive tract, water from slaughterhouses, meat handlers, air, soil or slaughterhouse floor, cutting equipment, meat handling equipment, transportation, and marketing places along with equipment and seller (Doyle and Beuchar, 2007; Purnama et al., 2019).

Based on the result obtained from total S. aureus count on beef in Tempurejo, Krempyeng Yamuri, Pacar Keling, dan Menur Wet Market in Mulyorejo Sub-district Surabaya, $S$. aureus count results from all samples surpassed the Standard Nasional Indonesia $7388: 2009$ or $1 \times 10^{2} \mathrm{CFU} / \mathrm{g}$. The average total $S$. aureus count in Tempurejo market was $9,3 \times 10^{2} \mathrm{CFU} / \mathrm{g}$, Krempyeng Yamuri market was $8,4 \times 10^{2}$ $\mathrm{CFU} / \mathrm{g}$, Pacar Keling market was $3,4 \times 10^{3} \mathrm{CFU} / \mathrm{g}$, and Menur market was $6,4 \times 10^{3} \mathrm{CFU} / \mathrm{g}$.

Dissemination of $S$. aureus among humans and from humans to food can occur through direct contact, indirectly through skin fragments, or through respiratory tract droplet nuclei (Doyle and Beuchar, 2007). Selling on meat stalls can also cause consumers to choose meat by touching the desired part of the meat so that the meat can easily be contaminated by microbes found in the hands of consumers (Sugiyoto et al., 2015).

\section{CONCLUSION}

Based on this research, it could be concluded that most Total Plate Count of beef at wet markets in Mulyorejo subdistrict were below the SNI 7388:2009 and the $S$. aureus count were exceeding SNI 7388:2009. Identification of $S$. aureus showed that $S$. aureus contamination occurred in $100 \%$ of 24 samples that were examined.

\section{REFERENCES}

Arisanti, R.R., C. Indriani and S.A. Wilopo. 2018. Kontribusi Agen dan Faktor Penyebab Kejadian Luar Biasa Keracunan Pangan di Indonesia: Kajian Sistematis. Berita Kedokteran Masyarakat vol. 34 (3): 99-106.

Badan Pengawas Obat dan Makanan Republik Indonesia. 2017. Laporan Kinerja 2017 Direktorat Surveilan dan Penyuluhan Keamanan Pangan. In: Laporan Akuntabilitas Kinerja Instansi Pemerintah Tahun 2017. p.43-44.

Brooks, G.F., J.S. Butel and S.A. Morse. 2008. Jawetz, Melnick, \& Adelberg Mikrobiologi Kedokteran. Penerbit Buku Kedokteran ECG. p.225-232.

Djaafar, T.F. and S. Rahayu. 2007. Cemaran Mikroba pada Produk Pertanian, Penyakit yang Ditimbulkan dan Pencegahannya. Jurnal Litbang Pertanian, 26 (2): 6775 .

Doyle, M.P. and L.R. Beuchar. 2007. Food Microbiology Fundamentals and Frontiers, Third Edition. Washington.

Fikri, F., Hamid, I. S., \& Purnama, M. T. E. (2017). Uji organoleptis, pH, uji eber dan cemaran bakteri pada karkas yang diisolasi dari kios di Banyuwangi. Jurnal Medik Veteriner, 1(1), 23-27.

Fikri, F., Purnama, M. T. E., Saputro, A. L., \& Hamid, I. S. (2018). Identifikasi Escherichia coli dan Salmonella spp pada Karkas Sapi di Rumah Potong Hewan di Banyuwangi dan Resistensi Terhadap Antibiotika. Sain Veteriner, 36(1), 123-128.

Fikri, F., \& Purnama, M. T. E. (2020). Biosecurity Application of Small Scale Chicken Abattoir in Sidoarjo, East 
Java, Indonesia. Systematic Reviews in Pharmacy, 11(6), 226-229.

International Agency for Research on Cancer. 2018. Red Meat and Processed Meat. IARC Monographs on the Evaluation of Carcinogenic Risks to Humans vol. 114. Lyon, France.

Le Loir, Y., F. Baron and M. Gautier. 2003. Staphylococcus aureus and Food Poisoning. Genetics and Molecular Research 2 (1): 7-28.

Naully, P.G. and F. Mathilda. 2018. Pencegahan Penyakit akibat Jajanan Sekolah dengan Edukasi Kesehatan dan Undang-Undang Perlindungan Konsumen. Gemassika: Jurnal Pengabdian Kepada Masyarakat vol. 2 (2): 80-90.

Nurhadi, M. 2012. Kesehatan Masyarakat Veteriner (Higiene Bahan Pangan Asal Hewan dan Zoonosis). Gosyen Publishing. Yogyakarta.
Purnama, M. T. E., Dewi, W. K., Prayoga, S. F., Triana, N. M., Aji, B. S. P., Fikri, F., \& Hamid, I. S. (2019). Preslaughter stress in banyuwangi cattle during transport. Indian Vet. J, 96(12), 5052.

Sugiyoto, K. Adhiyanto and V. Wanniatie. 2015. Kandungan Mikroba pada Daging Sapi dari Beberapa Pasar Tradisional di Bandar Lampung. Jurnal Ilmiah Peternakan Terpadu vol. 3 (2): 27-30.

Supar and T. Ariyanti. 2005. Keamanan pangan produk peternakan ditinjau dari aspek prapanen: permasalahan dan solusi. Prosiding Lokakarya Nasional Keamanan Pangan Produk Peternakan, Bogor, 14 September 2005. Pusat Penelitian dan Pengembangan Peternakan, Bogor. p 27-29. 